\title{
Community Empowerment in Facing Covid-19 Disaster by KKN Students of Universitas Sebelas Maret in Wonosobo District
}

\section{Chatarina Muryani, Fransisca Trisnani Ardikha Putri, Puji Lestari, Rahendhiki Ratik Galindra, Ainaya Nurrachma Hakim, Almara Yoyok Arighynata, Danang Mika Daya, Dika Ulfatus Sa' Adah, Rima Reniesa Pelita Rianti, Dwitama Alphin Usdianto, Lulu Febriana Damayanti}

Universitas Sebelas Maret

chatarinamuryani@staff.uns.ac.id

Article History

accepted 31/08/2020

approved 22/09/2020

published $28 / 10 / 2020$

\begin{abstract}
Sebelas Maret University Real Work Lecture (KKN) during the COVID-19 pandemic was still carried out with a focus on problems that occurred during the COVID-19 pandemic. The location for the Covid-19 KKN placement is also specifically in the Neighborhood (RT) where the KKN students live. In the Wonosobo Regency area there are 10 Sebelas Maret University students who are undergoing KKN, they are members of the Group 170 UNS Covid-19 Batch-2 $K K N$. These students have successfully carried out community empowerment activities in the form of (1) Socialization to the community about COVID-19 and food security, (2) Training and practices related to family resilience in the face of the COVID-19 pandemic, including training and practice of making masks, making hand sanitizers, planting vegetables in hydroponics and planting in pots and family waste. Based on the family resilience survey that has been carried out, as many as $70 \%$ of the respondent's families are in the high family toughness category.
\end{abstract}

Keywords: UNS Community Service, COVID-19, Community Empowerment, Family

Resilience.

\begin{abstract}
Abstrak
Kuliah Kerja Nyata (KKN) Universitas Sebelas Maret di masa pandemik COVID-19 tetap dilaksanakan dengan fokus pada permasalahan yang terjadi saat pandemik COVID-19. Lokasi penempatan KKN Covid-19 ini juga terkhusus pada Rukun Tetangga (RT) dimana mahasiswa KKN tersebut tinggal. Di wilayah Kabupaten Wonosobo terdapat 10 mahasiswa Universitas Sebelas Maret yang sedang menjalani KKN, mereka tergabung dalam KKN UNS Covid-19 Batch-2 Kelompok 170. Para mahasiswa ini telah berhasil menjalankan kegiatan pemberdayaan masyarakat yang berupa (1) Sosialisasi kepada masyarakat tentang COVID-19 dan ketahanan pangan, (2) Pelatihan dan praktek yang berkaitan dengan ketangguhan keluarga dalam menghadapi pandemik COVID-19 antara lain pelatihan dan praktek pembuatan masker, pembuatan hand sanitizer, penanaman sayuran secara hidroponik dan penanaman dalam pot dan limbah keluarga. Berdasarkan survey ketangguhan keluarga yang sudah dilakukan, sebanyak 70 \% keluarga responden termasuk kategori ketangguhan keluarga tinggi Kata kunci: KKN UNS, COVID-19, Pemberdayaan Masyarakat, Ketangguhan Keluarga.
\end{abstract}

Social, Humanities, and Education Studies (SHEs): Conference Series https://jurnal.uns.ac.id/shes

p-ISSN 2620-9284

e-ISSN 2620-9292 


\section{PENDAHULUAN}

Dalam Undang-Undang RI Nomor 17 Tahun 2007 tentang Pembangunan Jangka Panjang Nasional Tahun 2005-2025 disebutkan bahwa Visi pembangunan nasional adalah "Indonesia yang Mandiri, Maju, Adil dan Makmur" (Undang-Undang Republik Indonesia No 17, 2007). Salah satu unsur penting bagi pembangunan sumber daya manusia adalah derajat kesehatan. Untuk mencapai derajat kesehatan yang setinggitingginya, Pemerintah Indonesia telah menetapkan tujuan pembangunan kesehatan, yang dinyatakan dalam Undang-Undang Nomor 36 Tahun 2009 tentang Kesehatan (Undang-Undang Republik Indonesia No 36, 2009). Pembangunan kesehatan bertujuan untuk meningkatkan kesadaran, kemauan, dan kemampuan hidup sehat bagi setiap orang agar terwujud derajat Kesehatan masyarakat yang setinggi-tingginya dengan memberdayakan dan mendorong peran aktif masyarakat dalam segala bentuk upaya kesehatan. Dalam rangka melindungi masyarakat, Pemerintah menetapkan tujuan penanggulangan bencana yang dinyatakan dalam Undang-undang Nomor 24 Tahun 2007 tentang Penanggulangan Bencana (Undang-Undang Republik Indonesia No 24, 2007). UU 24 Tahun 2007 menyatakan bahwa penanggulangan bencana bertujuan untuk memberikan perlindungan kepada masyarakat dari ancaman bencana; menyelaraskan peraturan perundang - undangan yang sudah ada; menjamin terselenggaranya penanggulangan bencana secara terencana, terpadu, terkoordinasi dan menyeluruh; menghargai budaya lokal; membangun partisipasi dan kemitraan publik serta swasta; mendorong semangat gotong royong, kesetiakawan, dan kedermawanan; dan menciptakan perdamaian dalam kehidupan bermasyarakat, berbangsa dan bernegara.

Pemberdayaan masyarakat dalam penanggulangan krisis kesehatan, secara umum ditujukan pada meningkatnya kemandirian masyarakat dalam penanggulangan krisis kesehatan. Secara khusus ditujukan untuk (Kemenkes RI, 2015a) :

a. Meningkatnya pengetahuan masyarakat dalam penanggulangan krisis kesehatan

b. Meningkatnya kemampuan masyarakat dalam pemeliharaan dan peningkatan kemampuannya mengurangi risiko bencana dan kesehatannya sendiri;

c. Meningkatnya pemanfaatan fasilitas pelayanan Kesehatan oleh masyarakat; dan

d. Terwujudnya pelembagaan upaya kesehatan bersumber daya masyarakat untuk ketangguhan masyarakat.

Kerugian fisik, sosial dan ekonomi yang disebabkan oleh keterpaparan bencana sangat parah bagi negara-negara berkembang karena memiliki efek jangka panjang dalam proses pembangunan. Oleh sebab itu penting untuk penekanan upaya penanggulangan bencana berfokus pada komunitas dan masyarakat yang tinggal di dalamnya. Unsur paling umum dari keterlibatan masyarakat adalah kemitraan, partisipasi, pemberdayaan, dan kepemilikan oleh masyarakat lokal (Rajeev, 2014).

Mulai awal bulan Maret tahun 2020 di Indonesia dinyatakan terpapar pandemik Covid-19. Corona virus Disease-19 (COVID-19) merupakan penyakit menular yang disebabkan oleh virus SARS-COV 2 atau Virus Corona. COVID-19 dinyatakan sebagai pandemi dunia oleh WHO dan ditetapkan Pemerintah sebagai bencana non alam berupa wabah penyakit yang perlu dilakukan langkah-langkah penanggulangan terpadu termasuk keterlibatan seluruh komponen masyarakat. Sudah lebih dari lima bulan berlangsung, namun tanda - tanda pandemik tersebut berakhir belum nampak. Oleh sebab itu kemandirian masyarakat untuk beradaptasi dengan memperhatikan protokol kesehatan yang ditetapkan oleh pemerintah harus terus ditingkatkan agar masyarakat tetap dapat beraktivitas meskipun terbatas,

Kemandirian masyarakat merupakan suatu kondisi yang dialami oleh masyarakat yang ditandai dengan kemampuan memikirkan, memutuskan serta melakukan sesuatu 
yang dipandang tepat demi mencapai pemecahan masalah-masalah yang dihadapi dengan mempergunakan daya kemampuan yang dimiliki. Daya kemampuan yang dimaksud adalah kemampuan kognitif, konatif, psikomotorik dan afektif serta sumber daya lainnya yang bersifat fisik/ material (Widjajanti, 2011). Hal ini terkait karena masyarakatlah yang mengetahui kemampuan dan kelemahan mereka sendiri (Sachinkumar, 2012).

Pendekatan pemberdayaan masyarakat menjadi salah satu cara dalam pengembangan masyarakat mandiri. Pemberdayaan mempunyai arti membangkitkan sumber daya, kesempatan, pengetahuan, dan keterampilan untuk meningkatkan kapasitas masyarakat dalam menentukan dan mengembangkan dirinya (Subekti, Setianti, \& Hafiar, 2018). Pemberdayaan masyarakat dalam pencegahan COVID-19 adalah segala upaya yang dilakukan oleh seluruh komponen masyarakat dengan menggali potensi yang dimiliki masyarakat agar berdaya dan mampu berperan serta mencegah penularan COVID-19 (Kemenkes RI, 2015b).

Program KKN Universitas Sebelas Maret di masa pandemik COVID-19 ini dilakukan menyesuaikan situasi dan kondisi, yaitu KKN di wilayah Rukun Tetangga (RT) di mana mahasiswa itu tinggal dan kegiatan yang dilakukan berupa kegiatankegiatan yang berkaitan dengan pencegahan dan penguatan masyarakat dalam menghadapi pandemik COVID-19. Tujuan penulisan artikel ini adalah untuk desiminasi kegiatan-kegiatan yang telah dilakukan oleh mahasiswa peserta KKN periode Februari - Juli 2020 Di Kabupaten Wonosobo Provinsi Jawa Tengah.

\section{METODE}

Lokasi kegiatan KKN mahasiswa Universitas Sebelas Maret adalah di Kabupaten Wonosobo. Ada 10 mahasiswa yang ditempatkan di lokasi ini, terdiri dari 10 wilayah Rukun Tetangga (RT). Program pemberdayaan masyarakat untuk ketangguhan masyarakat dalam menghadapi pandemik COVID-19 adalah:

1. Sosialisasi bertujuan untuk transfer ilmu tentang pandemik COVID-19, protokol dalam kehidupan sehari-hari agar terbebas dari ancaman virus corona, dan kegiatan-kegiatan ekonomi yang dapat menambah penghasilan penduduk atau mengurangi pengeluaran kebutuhan sehari-hari

2. Pelatihan, bertujuan untuk menambah ketrampilan penduduk dalam menghadapi pandemik COVID-19

3. Praktek bertujuan untuk mempraktekkan pelatihan yang telah dilakukan

4. Survey ketangguhan keluarga terhadap COVID-19, dilakukan untuk mengetahui tingkat ketangguhan keluarga terhadap bencana (KATANA) COVID-19. Masing-masing RT diambil sampel sebanyak $20 \mathrm{KK}$ secara acak, sehingga untuk $10 \mathrm{RT}$ terdapat $=10 \times 20=200$ sampel responden.

\section{Deskripsi Daerah Kegiatan}

\section{HASIL DAN PEMBAHASAN}

Kabupaten Wonosobo merupakan salah satu dari 35 Kabupaten/ Kota di Provinsi Jawa Tengah yang terletak pada 7011'20" - 7036'24" LS, 109044'08" - 110004'32" BT, dengan luas wilayah 98.468 hektar $(984,68 \mathrm{~km} 2)$ atau 3,03\% luas Provinsi Jawa Tengah. (Kabupaten Wonosobo dalam angka 2019). Kabupaten Wonosobo berjarak 120 km dari ibu kota Jawa Tengah (Semarang) dan 520 km dari lbu kota Negara (Jakarta), berada pada rentang $250 \mathrm{dpl}-2.250 \mathrm{dpl}$ dengan dominasi pada rentang 500 $\mathrm{dpl}-1.000 \mathrm{dpl}$ sebesar 50\% (persen) dari seluruh areal, menjadikan ciri dataran tinggi sebagai wilayah Kabupaten Wonosobo dengan poisi pasial berada di tengah-tengah Pulau Jawa dan berada diantara jalur pantai utara dan jalur pantai selatan. Selain itu menjadi bagian terpenting dari jaringan Jalan Nasional ruas jalan Buntu - Pringsurat yang memberi akses dari dan menuju dua jalur strategis nasional tersebut. 
Luas wilayah sebesar itu secara administrasi terbagi dalam 15 kecamatan yang terdiri dari Kecamatan Wadaslintang, Kepil, Sapuran, Kalibawang, Kaliriwo, Leksono, Sukoharjo, Selomerto, Kalikajar, Kertek, Wonosobo, Watumalang, Mojotengah, Garung dan Kejajar. Kabupaten Wonosobo secara administrasi berbatasan dengan Kabupaten Banjarnegara, Kabupaten Kendal dan Kabupaten Batang di sebelah utara; berbatasan dengan Kabupaten Temanggung dan Kabupaten Magelang di sebelah timur; berbatasan dengan Kabupaten Purworejo dan Kabupaten Kebumen di sebelah selatan dan berbatasan dengan Kabupaten Banjarnegara dan Kabupaten Kebumen di sebelah barat.

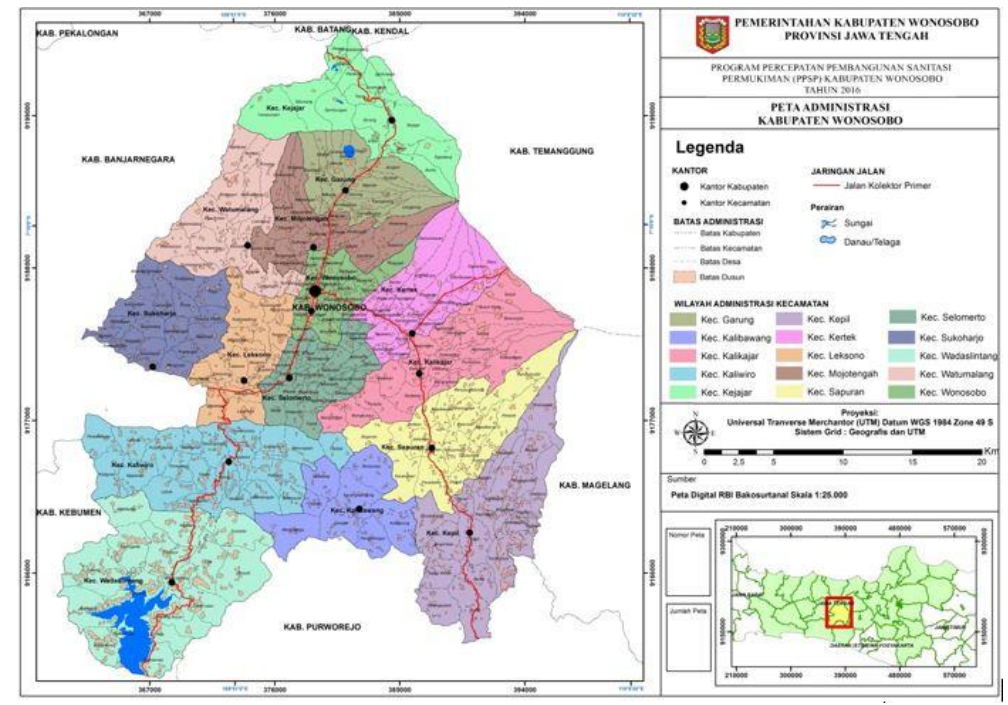

Gambar 1. Peta Administrasi Kabupaten Wonosobo

Sebagian besar wilayah Kabupaten Wonosobo adalah daerah pegunungan. Bagian timur (perbatasan dengan Kabupaten Temanggung) terdapat dua gunung berapi: Gunung Sindoro (3.136 meter) dan Gunung Sumbing (3.371 meter). Daerah utara merupakan bagian dari Dataran Tinggi Dieng, dengan puncaknya Gunung Prahu (2.565 meter). Di sebelah selatan, terdapat Waduk Wadaslintang. Ibu kota Kabupaten Wonosobo berada di tengah-tengah wilayah Kabupaten, yang merupakan daerah hulu Kali Serayu. Wonosobo dilintasi jalan provinsi yang menghubungkan SemarangPurwokerto.

\section{Pemberdayaan Masyarakat Untuk Ketangguhan Menghadapi pandemic COVID-19}

a. Sosialisasi Tentang Pandemik COVID-19

Virus Corona atau severe acute respiratory syndrome coronavirus 2 (SARS-CoV-2) adalah virus yang menyerang sistem pernapasan. Penyakit karena infeksi virus ini disebut COVID-19. Severe acute respiratory syndrome coronavirus 2 (SARS-CoV-2) yang lebih dikenal dengan nama virus Corona adalah jenis baru dari coronavirus yang menular ke manusia. Virus ini bisa menyerang siapa saja, seperti lansia (golongan usia lanjut), orang dewasa, anak-anak, dan bayi, termasuk ibu hamil dan ibu menyusui. Virus Corona bisa menyebabkan gangguan ringan pada sistem pernapasan, infeksi paru-paru yang berat, hingga kematian.

Dalam rangka memasyarakatkan hidup sehat untuk mencegah penularan virus corona di antara warga masyarakat, telah dilakukan berbagai sosialisasi oleh mahasiswa KKN UNS kepada masyarakat, antara lain :

- Informasi tentang virus corona, karakteristik cara penularan dan dampaknya terhadap manusia. 
- Sosialisasi fungsi masker untuk perlindungan Kesehatan, kriteria masker yang baik dan cara pemakaian masker yang benar

- Sosialisasi manfaat hand sanitizer dan sosialisasi tentang manfaat cuci tangan, prosedur cuci tangan yang betul

- Sosialisasi tentang jaga jarak (social distancing)manfaat serta bagaimana pelaksanaanya

- Sosialisasi tentang manfaat disinfektan serta bagaimana pemakaian

Sosialissi tersebut ada yang berupa pertemuan secara luring, dan yang lain pakai daring misalnya WhatsApp grup, E-mail, Instagram atau Zoom Meeting, dan sebagainya; pembuatan dan pemasangan poster di tempattempat strategis, pembuatan video yang diunggah di Youtube.
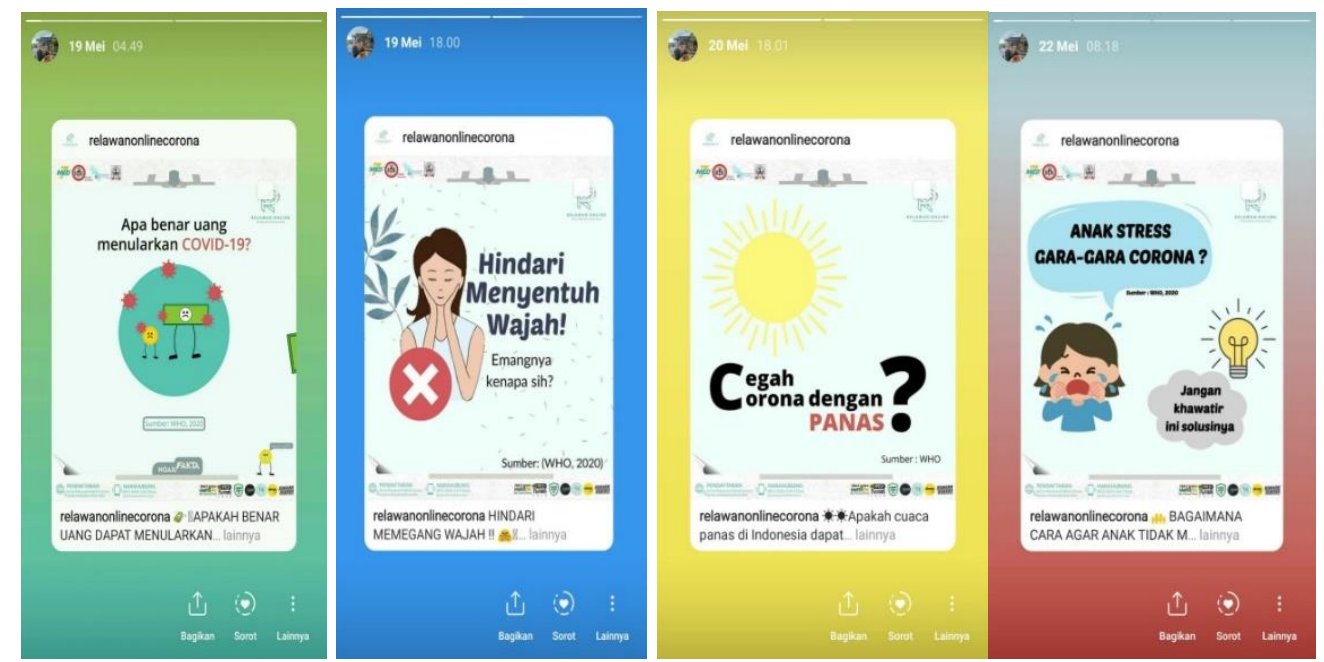

Gambar 2. Contoh Sosialisasi Covid-19 dengan Poster

Sosialisasi yang lain adalah tentang ketahanan pangan keluarga, misalnya bagaimana menanam sayuran dalam pot, tanaman obat keluarga, dan lain-lain.

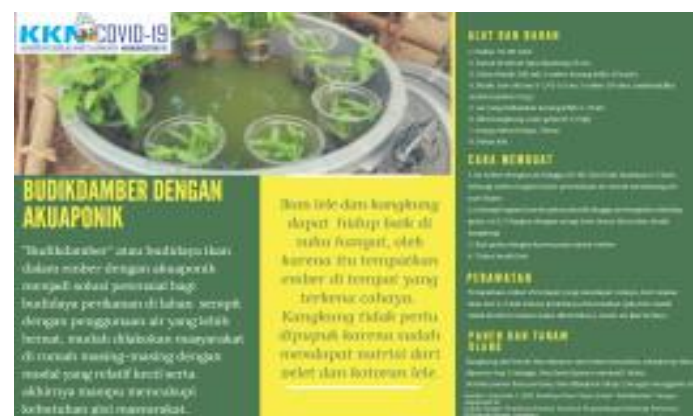

Gambar 3. Contoh Poster Pembuatan Akuaponik

Akuaponik pada lokasi KKN bertujuan untuk membangun ketahanan pangan pada wilayah yang terdampak dari pandemi covid-19 sehingga wilayah KKN menjadi tangguh ekonomi dan tangguh pangan karena mampu membuat dan menciptakan sendiri kebutuhan pangannya dalam memenuhi kebutuhan hidupnya. Proses pembuatan akuaponik juga dinilai lebih efektif karena tidak 
perlu media tanam (tanah) yang luas dan memanfaatkan botol bekas pakai dan mudah di buat pada masing-masing keluarga.

b. Pelatihan dan Praktek

Disamping sosialisasi juga diadakan pelatihan sekaligus praktek beberapa ketrampilan. Ketrampilan yang dilatihkan disamping untuk keperluan pribadi, juga diarahkan menjadi usaha yang dapat mendatangkan penghasilan. Beberapa pelatihan dan praktek yang dilakukan oleh mahasiswa KKN UNS adalah:

- Pelatihan membuat masker

- Pelatihan membuat hand saitizer

- Pelatihan penanaman sayuran dengan system hidroponik

- Pelatihan penanaman sayuran dan tanaman lain secara vertical dengan wadah barang-barang bekas

- Pelatihan pembuatan masker
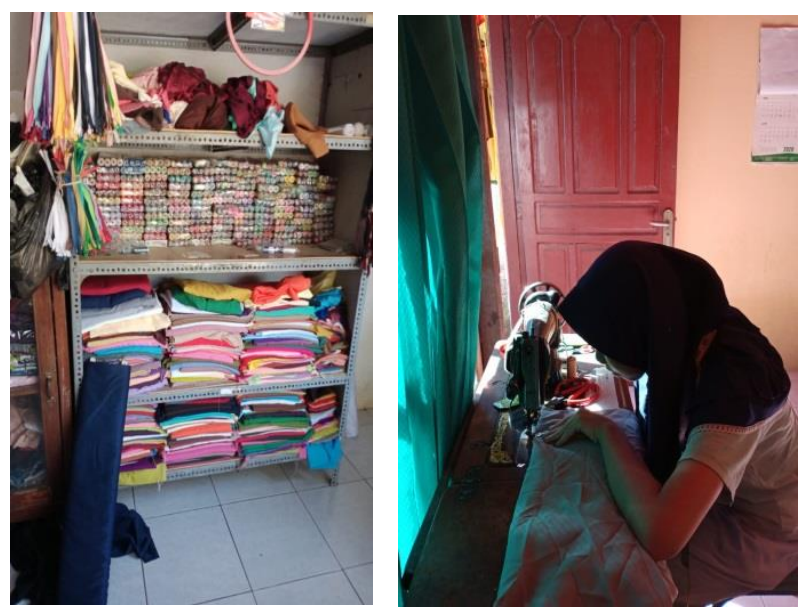

Gambar 4. Proses Pembuatan Masker

Contoh ketika salah satu warga RT 05 RW 01 yang dinyatakan reaktif COVID-19 bersama dengan pak RT dan tenaga kesehatan sehingga tim KKN UNS berinisiatif untuk memroses pembuatan masker yang dijahit oleh warga dua orang warga RT 05 RW 01 yang berprofesi sebagai penjahit. Masker dibagikan kepada warga sekitar sekaligus untuk mengedukasi masyarakat tentang anjuran memakai masker dengan baik dan benar untuk menghindari droplet.

c. Edukasi untuk anak sekolah

Kegiatan lain adalah dengan mengadakan kegiatan di bidang Pendidikan yaitu dengan mengadakan les gratis bagi anak-anak Sekolah Dasar. Kegiatan ini diadakan secara luring tetapi dalam jumlah terbatas dan bergiliran.

\section{Survey Ketangguhan Keluarga terhadap Pandemik COVID-19}

Pada akhir kegiatan KKN UNS diadakan survey ketangguhan keluarga dalam menghadapi bencana pandemic COVID-19. Survey dengan menggunakan metode wwancara menggunakan kuesionair yang dikirimkan melalui WA-group kepada 20 warga RT dimana mahasiswa KKN UNS tersebut tinggal. Oleh karena mahasiswa KKN ada 10 mahasiswa, maka sampel terkumpul 200 orang. Indikator keluarga Tangguh 
bencana adalah (1) pengetahuan tentang COVID-19, (2) Kesadaran keluarga akan ancama pandemik COVID-19, dan (3). Berdaya untuk Tangguh.

Hasil analisis jawaban responden yang terkumpul dapat dilihat di bawah ini:

Tabel 1. Total Skor Indikator dan Kategori KATANA Covid-19

\begin{tabular}{lcc}
\hline \multicolumn{1}{c}{ Wilayah } & \multicolumn{2}{c}{ KATANA } \\
\cline { 2 - 3 } & $\begin{array}{c}\text { Total } \\
\text { Skor } \\
\text { Indikator }\end{array}$ & Kategori \\
\hline RT 05/ RW 06 Desa Karangluhur, Kertek, Wonosobo & 874 & $\begin{array}{c}\text { Ketangguhan } \\
\text { Tinggi }\end{array}$ \\
\hline $\begin{array}{l}\text { RT 09/RW 03 Pesuruhan, Ngadisono, Kaliwiro, } \\
\text { Wonosobo }\end{array}$ & 795 & $\begin{array}{c}\text { Ketangguhan } \\
\text { Tinggi }\end{array}$ \\
\hline RT 05/RW 06 Jlamprang,Wonosobo & 830 & $\begin{array}{c}\text { Ketangguhan } \\
\text { Tinggi }\end{array}$ \\
\hline $\begin{array}{l}\text { RT 01 RW 07 Kp. Kliwonan Timur, Kel. Wonosobo } \\
\text { Barat, Kec. Wonosobo, Kab. Wonosobo }\end{array}$ & 783 & $\begin{array}{c}\text { Ketangguhan } \\
\text { Sedang }\end{array}$ \\
\hline $\begin{array}{l}\text { RT 05/ RW 04, Mlipak, Wonosobo } \\
\text { Krasak, Mojotengah, Wonosobo }\end{array}$ & 842 & $\begin{array}{c}\text { Ketangguhan } \\
\text { Tinggi }\end{array}$ \\
\hline $\begin{array}{l}\text { RT04/RW02 Kel. Wonosobo Timur, Wonosobo } \\
\text { RT 03 RW 02 Mlipak,Kec Wonosobo }\end{array}$ & 881 & $\begin{array}{c}\text { Ketangguhan } \\
\text { Tinggi }\end{array}$ \\
\hline $\begin{array}{l}\text { Perumahan Asli Permai RT 07 /RW 05, Kel. } \\
\text { Kramatan, Kec. Wonosobo, Kab. Wonosobo }\end{array}$ & 883 & $\begin{array}{c}\text { Ketangguhan } \\
\text { Tinggi }\end{array}$ \\
\hline Kaliwiro, Wonosobo & 786 & $\begin{array}{c}\text { Ketangguhan } \\
\text { Sedang }\end{array}$ \\
\hline
\end{tabular}

Dari tabel di atas terlihat bahwa wilayah mahasiswa kkn di Kabupaten Wonosobo memiliki Katana Covid-19 di Kabupaten Wonosobo dengan Kategori Ketangguhan Tinggi Sebesar 70\% dan Kategori Ketangguhan Sedang sebesar 30\% Katana Covid19. Dapat dilihat bada gambar diagram presentase berikut :

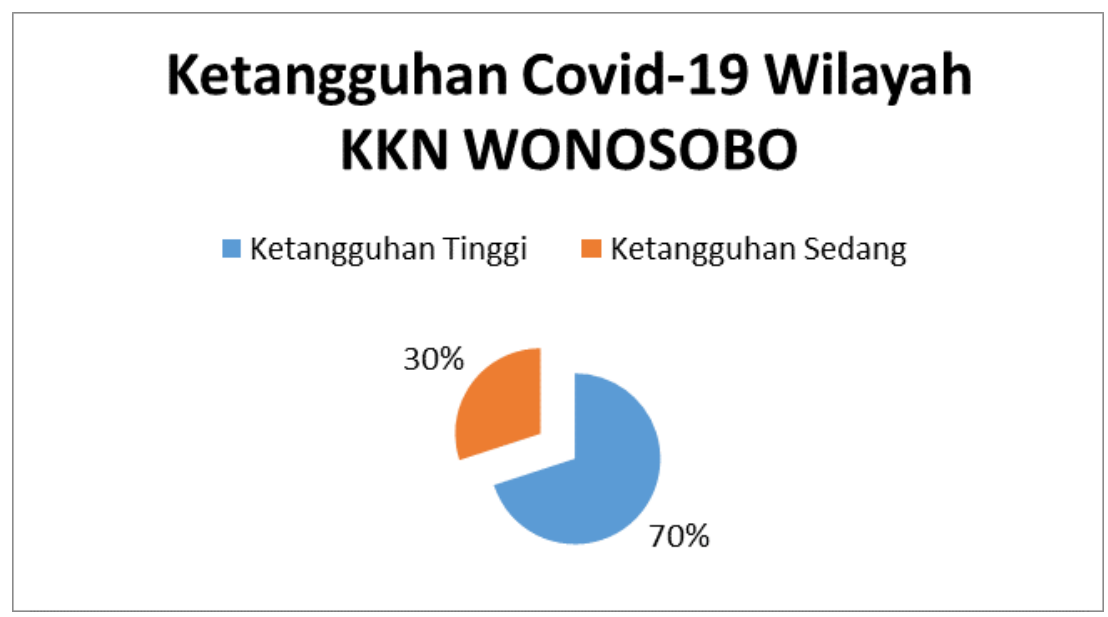

Gambar 5. Ketangguhan Keluarga terhadap pandemic COVID-19 di lokasi KKN UNS Kabupaten Wonosobo 


\section{SIMPULAN}

Dari uraian di atas dapat disimpulkan sebagai berikut:

1. Program KKN-UNS di Kabupaten Wonosobo yang terdiri atas 10 mahasiswa dari berbagai Fakultas dan Program Studi telah berhasil melaksanakan kegiatan pemberdayaan masyarakat berupa sosialisasi tentang pandemic COVID-19 dan ketahanan pangan keluarga, pelatihan dan praktek ketrampilan pembuatan masker, hand sanitizer, tempat cuci tangan, menanam hidroponik dan pemanfaatan limbah keluarga untuk penanaman sayur.

2. Tingkat ketangguhan keluarga dalam menghadapi pandemik COVID-19 termasuk kategori tinggi.

\section{DAFTAR PUSTAKA}

Kemenkes RI. (2015a). Pedoman Pemberdayaan Masyarakat dalam Penanggulangan Krisis Kesehatan.

Kemenkes Rl. (2015b). Pedoman Pemberdayaan Masyarakat Dalam Pencegahan COVID-19 Di RT/RW/Desa. In Journal of Chemical Information and Modeling (Vol. 53). https://doi.org/10.1017/CBO9781107415324.004

Rajeev, M. M. (2014). Sustainability and Community Empowerment in Disaster Management. International Journal of Social Work and Human Services Practice, 2(6), 207-212.

Sachinkumar, B. N. (2012). Community-based disaster management strategy in india: an experience sharing. Journal for Nature Conservation, 3(1), 1-7. https://doi.org/10.1063/1.4753937

Subekti, P., Setianti, Y., \& Hafiar, H. (2018). Pemberdayaan Masyarakat Berbasis Lingkungan Hidup Di Desa Margalaksana Kabupaten Bandung Barat. Jurnal Kawistara, 8(2), 148. https://doi.org/10.22146/kawistara.30379

Undang-Undang Republik Indonesia No 17 Tahun 2007. (2007). Combustion Science and Technology, 21(5-6), 1-49. Retrieved from https://doi.org/10.1080/00102208008946937

Undang-Undang Republik Indonesia No 24 Tahun 2007. (2007).

Undang-Undang Republik Indonesia No 36 Tahun 2009. (2009). Atmospheric Chemistry and Physics, 7(1), 1-13. https://doi.org/10.1029/2008GB003237

Widjajanti, K. (2011). MODEL PEMBERDAYAAN MASYARAKAT. 12. 